\title{
Note \\ Characterization and selection of Bacillus thuringiensis isolates effective against Sitophilus oryzae
}

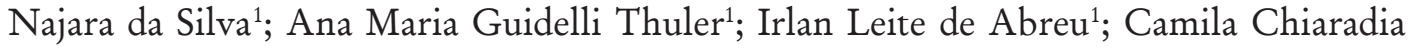 \\ Davolos $^{1}$; Ricardo Antonio Polanczyk ${ }^{2}$; Manoel Victor Franco Lemos ${ }^{1 \%}$ \\ ${ }^{1}$ UNESP/FCAV - Depto. de Biologia Aplicada à Agropecuária - Via de Acesso Prof. Paulo Donato Castellane, \\ s/n - 14884-900 - Jaboticabal, SP - Brasil. \\ ${ }^{2}$ UFES/CCA - Depto. de Produção Vegetal - Alto Universitário s/n. - 29500-000 - Alegre, ES - Brasil. \\ *Corresponding author <mvictor@fcav.unesp.br>
}

\begin{abstract}
The entomopathogenic bacterium Bacillus thuringiensis is a control agent with toxic and environmental characteristics that allows the control of pest insects according to the Integrate Pest Management (IPM) precepts. In order to find new strains, potentially toxic to Sitophilus oryzae L. 1763 (Coleoptera: Curculinidae), 1.073 strains of $B$. thuringiensis from parts of Brazil were used. Genetic material was extracted with InstaGene Matrix kit, used for the amplification of sequences in Polymerase chain reaction (PCR), and viewed in $1.5 \%$ agarose gel. The gene cry $35 \mathrm{Ba}$ class was represented by $60 \mathrm{~B}$. thuringiensis isolates (5.6\%), which were then subjected to bioassays with $S$. oryzae larvae. Among the isolates studied, four caused more than $50 \%$ mortality in pathogenicity tests, and the isolates 544 and 622 were the most virulent, as determined by $\mathrm{CL}_{50}$ estimates. The four toxic isolates had spherical, bi-pyramidal and cuboid crystals, and a 44-kDa protein was found in sodium dodecyl sulphate - polyacrylamide gel electrophoresis (SDS-PAGE), which coded for the product of $\mathrm{cry} 35 \mathrm{Ba}$ genes. These data demonstrate the potential of $B$. thuringiensis for the management of $S$. oryzae larvae.
\end{abstract}

Key words: Coleoptera, Curculionidade, crystal protein, entomopathogenic bacterium

\section{Caracterização e seleção de isolados de Bacillus thuringiensis efetivos contra Sitophilus oryzae}

\begin{abstract}
RESUMO: A bactéria entomopatogênica Bacillus thuringiensis (Bt) é um agente de controle com características tóxicas e ambientais que permitem o controle de insetos-praga de acordo com as premissas do Manejo integrado de pragas (MIP). Com o objetivo de buscar novas linhagens potencialmente tóxicas para Sitophilus oryzae L. 1763 (Coleoptera: Curculinidae), caracterizaram-se molecularmente 1,073 isolados de B. thuringiensis de regiões do Brasil. O material genético foi extraído através do kit InstaGene Matrix, utilizado para a amplificação das seqüências através da técnica de Polymerase chain reaction PCR, sendo os resultados visualizados em gel de agarose $1,5 \%$. A classe do gene cry $35 \mathrm{Ba}$ foi representada por 60 isolados $(5,6 \%)$ de $B t$, os quais foram submetidos a bioensaio com larvas de S. oryzae. Quatro causaram mortalidade acima de $50 \%$ nos testes de patogenicidade e os isolados 544 e 622 foram os mais virulentos, conforme determinado pela estimativa da CL $_{50}$. Nos quatro isolados que demonstraram toxicidade, foram detectados cristais esféricos, bipiramidais e cubóides, além de proteínas com $44 \mathrm{kDa}$, referentes aos genes cry35Ba por Sodium dodecil sulphate - polyacrilamide gel electrophoresis (SDS-PAGE). Estes dados demonstram o potencial de Bt no manejo de $S$. oryzae.

Palavras-chave: bactéria entomopatogênica, Coleoptera, Curculionidae, proteína cristal
\end{abstract}

\section{Introduction}

Among the factors that affect grain cereals during storage periods is the attack by the pest insect Sitophilus oryzae L. 1763 (Coleoptera: Corculinidae) larvae, which is particularly important, under tropical conditions, when the grains become an ideal habitat for its development (Athié and Paula, 2002). This pest also presents the characteristic of cross infestation, i.e., it can migrate from the field to the warehouse, which significantly increases its damage potential (Gallo et al., 2002).

The control of this pest is currently carried out with chemical insecticides that can be toxic also to man and to the environment. The entomopathogenic bacterium Bacillus thuringiensis, applied as a bioinsecticide, or its genetic material inserted into plants, known as genetically modified organisms, is today one of the major alternatives to chemical control (Federici, 2005; Glare and O'Callagham, 2000; Praça et al., 2004). This bacterium is noteworthy for producing, during the sporulation process, one or more toxic protein inclusions called Cry proteins (Bravo et al., 2005), and its pathogenicity and specificity are determined by the functional cry gene types that an isolate possess (Crickmore, 2008).

The toxic activity of a binary group of insecticide proteins (Moellenbeck et al., 2001) belonging to the 
classes Cry34 and Cry35, toxic for Diabrotica virgifera larvae was reported by Ellis et al. (2002). This new mode of action was observed in pathogenicity and virulence bioassays, and also in genetically modified maize (Schnepf et al., 2005; Storer et al., 2006).

This study characterized several $B$. thuringiensis isolates that contain the cry35Ba gene among others and show insecticidal effect against $S$. oryzae larvae and determined the morphological a total protein profiles of the isolates.

\section{Material and Methods}

Isolate's cultivation: One thousand seventy three isolates of $B$. thuringiensis collected from several locations in Brazil, and also belonging to the collection of the Laboratório de Genética de Bactérias e Biotecnologia Aplicada (LGBBA) from the Department of Applied Biology and Agriculture, Faculdade de Ciências Agrárias Veterinárias, UNESP - Campus Jaboticabal, were analyzed. These isolates were stored in the form of spores, adsorbed in sterile filter paper strips, and maintained in plastic tubes, with ultrapure sterile water, in a refrigerator, kept at $10^{\circ} \mathrm{C}$. An aliquot of each of the bacterial suspension was removed and spread on Nutrient Agar $(3 \mathrm{~g}$ $\mathrm{L}^{-1}$ meat extract, $5 \mathrm{~g} \mathrm{~L}^{-1}$ bacteriological peptone and $15 \mathrm{~g}$ $\mathrm{L}^{-1}$ agar), with the aid of a platinum loop in disposable Petri plates. The plates were incubated at $30^{\circ} \mathrm{C}$ for $12 \mathrm{~h}$ in an incubator.

Molecula characterization of the cry 35 gene: Total DNA samples of the 1,073 isolates were extracted using the ionic exchange resin of Insta-Gene Matrix kit (Bio$\left.\operatorname{Rad}^{\circledR}\right)$, according to the manufacturer's instructions; the supernatants containing the genetic material were transferred to a set of polypropylene plates with 96 wells. The DNA samples were stored at $-20^{\circ} \mathrm{C}$ in a freezer until their use.

Primers were designed for the sequence of $\operatorname{cry} 35 \mathrm{Ba}$ gene deposited on special data banks such as http:// www.lifesci.sussex.ac.uk/home/Neil_Crickmore/Bt/ toxins2.html, using the software Gene Runner 3.0 (Hastings Software, Inc.) and Clustal $W$ for sequence alignment and identification of conserved regions (Thompson et al., 1994). They are listed in Table 1 and were used for the identification of the cry35Ba gene.

The bacterial isolates DNA samples were subjected to PCR in reaction batches and in all it was used a negative control, substituting the DNA templates for water. These reactions included buffer $\left(200 \mathrm{mmol} \mathrm{L}{ }^{-1}\right.$ Tris, 500 mmol L-1 KCl, pH 8.4) $1 \mathrm{mmol} \mathrm{L}^{-1}$ magnesium chloride, $250 \mu \mathrm{mol} \mathrm{L} \mathrm{L}^{-1} \mathrm{dNTPs}$ solution, $10 \mathrm{pmol} \mu \mathrm{L}^{-1}$ of each primer for gene cry35Ba, $1 \mathrm{U}$ Taq DNA polymerase
(INVITROGEM), 30 ng de DNA template and Milli-Q filtered and sterilized water (enough amount to complete $20 \mu \mathrm{L}$ ).

These reactions were placed in a thermocycler (PTC100 MJ Research, $\operatorname{Inc}^{\circledR}$ ) programmed with a first five min denaturation step at $94^{\circ} \mathrm{C}$, followed by 35 cycles consisting of three steps: denaturation at $94^{\circ} \mathrm{C}$ for $30 \mathrm{~s}$; primer annealing at $40^{\circ} \mathrm{C}$ for $45 \mathrm{~s}$ and an extension period of one minute at $72^{\circ} \mathrm{C}$; and a last extension step at $72^{\circ} \mathrm{C}$ for seven min. It is important to point out that primer lower annealing temperatures need to be used since the nucleotide sequence difference between the cry genes detected on Lepidoptera and Coleoptera are quite similar and higher annealing temperatures would not allow the detection of PCR indicative bands. The final choice of which isolates really act on Coleoptera larvae was determined by the bioassays carried out in this study. Besides this, other authors have described the use of lower annealing temperatures Davolos et al. (2009) and Nazarian et al. (2009).

After amplification, $3 \mu \mathrm{L}$ buffer ("loading buffer" $0.5 \%$ bromophenol blue in glycerol $50 \%$ ) were added to each sample, and an aliquot of each amplified product was analyzed by electrophoresis in 1.5\% agarose gel (Sambrook and Russel, 2001). Horizontal trays model Sunrise $^{\mathrm{TM}}$ Life Technologies ${ }^{\mathrm{TM}}$ and FB-SB2025 Fisher Scientific were used for the electrophoresis, in TBE buffer (Tris $89 \mathrm{mmol} \mathrm{L}^{-1}$, EDTA $2.5 \mathrm{mmol} \mathrm{L}{ }^{-1}$, Boric acid 89 mmol L-1 enough amount to complete $1000 \mathrm{~mL}$; $\mathrm{pH} 8.2$ ), with $0.5 \mu \mathrm{g} \mathrm{mL}^{-1}$ ethidium bromide. The amplicons still in the agarose gels were observed under UV light and registered in appropriate equipment, and evaluated using a negative image, with the use of the software Quantity-One (GEL DOC 2000 - Bio-Rad ${ }^{\circledR}$ ).

Insect rearing: $\mathrm{S}$. oryzae maintenance and reproduction was carried out in four 8-liter plastic recipients. Approximately $2.5 \mathrm{~kg}$ corn (Zea mays L.) were placed in each recipient and infested with 100 non sexed insects. The recipients were closed and population development monitoring was carried out through the clear sides of the recipients, without moving the kernel mass. The insects were used in the bioassays six months after the start of mass rearing.

Bioassays: Pathogenicity was evaluated in $60 \mathrm{~B}$. thuringiensis isolates, identified by the amplification of the cry35Ba gene, from all 1,073 isolates screened by molecular techniques. The isolates were grown in nutrient broth $\left(3 \mathrm{~g} \mathrm{~L}^{-1}\right.$ meat extract, $5 \mathrm{~g} \mathrm{~L}^{-1}$ bacteriological peptone) at $28^{\circ} \mathrm{C}, 180 \mathrm{rpm}$, for $76 \mathrm{~h}$, for the production of the protein crystals. Subsequently the suspensions were subjected to three consecutive centrifugations at 2,655 $\chi$ $\mathrm{g}$ for $20 \mathrm{~min}$ to wash the sediments and remove the

Table 1 - Oligonucleotide sequences of primers.

\begin{tabular}{lcc}
\hline Denomination & \multicolumn{1}{c}{ Primer sequence } & Size \\
\hline \multirow{2}{*}{ cry35Ba } & F 5'AACTGATGAAATACCTGAAG3' & \multirow{2}{*}{$535 \mathrm{pb}$} \\
\hline
\end{tabular}

Sci. Agric. (Piracicaba, Braz.), v.67, n.4, p.472-478, July/August 2010 
growth medium excess. A $1 \mathrm{ml}$ aliquot of the resulting suspension was diluted 1,000 times in sterile distilled water, and the spore concentration was determined as described by Alves and Moraes (1998).

The sixty B.thuringiensis isolates were tested in six bioassays containing ten isolates one at a time. Each treatment consisted of seven repetitions of $20 \mathrm{~g}$ corn kernels. Six days before applying the treatments, the kernels were made available for 20 non sexed adults for oviposition during three days. After this process, the kernels were immersed, for $1 \mathrm{~min}$, in a suspension containing $3 \times 10^{8}$ spores $\mathrm{mL}^{-1}$ of the $B$. thuringiensis isolate being tested. Subsequently, the kernels were placed in sterile air flow hood to remove the excess moisture.

Mortality was calculated by the difference between the number of emerged insects in the treatments and those emerged from the control between 25 and 60 days after applying the treatments. Data correction was made using the formula proposed by Abbot (1925), and submitted to the Tukey test $(p<0.05)$.

Estimation of the average lethal concentration $\left(\mathrm{LC}_{50}\right)$ was carried out for the isolates that caused more than $50 \%$ mortality in the pathogenicity test. The conditions for running the bioassays, its evaluation, and the media for $B$. thuringiensis isolates suspension preparation were the same as those described for the pathogenicity test, with counts of $3 \times 10^{3}, 3 \times 10^{4}, 3 \times 10^{5}, 3 \times 10^{6}, 3 \times 10^{7}$ and $3 \chi 10^{8}$ spores $\mathrm{mL}^{-1}$.

Protein purification: was performed for the isolates that presented toxic activity against $S$. oryzae in the bioassays. The isolates were grown as described in item 2.1. Subsequently the bacterial mass was collected and transferred to nutrient broth $\left(3 \mathrm{~g} \mathrm{~L}^{-1}\right.$ meat extract, $5 \mathrm{~g} \mathrm{~L}^{-1}$ bacteriological peptone), and shacked in a rotating incubator at $200 \mathrm{rpm}$, and $30^{\circ} \mathrm{C}$ for $96 \mathrm{~h}$ until complete sporulation. Purifications were conducted by ultracentrifugation in sucrose gradient, according to Juárez-Perez et al. (2002).

Scanning electron microscopy: Isolate morphology was analyzed by scanning electron microscopy. A purified protein aliquot of each sample (spore/crystal) was spread over a glass cover slip with the aid of a bacteriological loop, and dried in a laminar flow hood. Subsequently the sample was fixed in a metal stub and covered with gold for $180 \mathrm{~s}$ using a metalizer, model K550, and analyzed in a Zeiss scanning electron microscope, model DSM 962.

Protein electrophoresis in polyacrylamide-SDS gel: The composition of the spore-crystal complex was analyzed by electrophoresis in polyacrylamide gel containing sodium dodecyl sulphate at 8 and $12 \%$. The samples containing spores-crystal were prepared with $62 \mathrm{mmol}$ $\mathrm{L}^{-1}$ Tris-HCl pH 6.8; 4\% SDS; $20 \%$ Glycerol; $5 \% \beta$ mercaptoethanol and $0.02 \%$ bromophenol blue, heated at $100^{\circ} \mathrm{C}$ for five min and centrifuged at $10,621 \chi \mathrm{g}$ for 30 s. SDS-PAGE electrophoresis was developed according to the method described by Laemmili (1970).

\section{Results and Discussion}

Pinto and Fiúza (2003) and Praça et al. (2004) have reported the characterization of $B$. thuringiensis isolates for the products of cry genes with activity against insects of the order Coleoptera, as well as for other ones, such as Lepidoptera and Diptera. The present study analyzed 1,073 isolates of $B$. thuringiensis, demonstrating that 60 isolates $(5.6 \%)$ contained the gene cry $35 B a$, and were selected for the bioassays, revealing that only four isolates (6.6\%) caused more than 50\% mortality of S. oryzae larvae (Figure 1).

The lack of efficacy against $S$. oryzae and the specificity of $B$. thuringiensis strains for different insect orders was confirmed by the use of the variety var. kurstaki HD1 as a negative control, since it does not present the gene cry $35 \mathrm{Ba}$, and caused only $4 \%$ mortality of $S$. oryzae lavae. The positive control had $26.30 \%$ efficacy against $S$. oryzae, represented by the variety var. tolworthi, which harbors the gene $c r y 35 B a$. It is relevant to highlight the importance of the present study, since new $B$. thuringiensis isolates are reported with efficacy above $50 \%$, thus surpassing the positive control.

The results obtained in the bioassays denoted differences in toxic activity presented by the isolates. The isolate 544 was the most active against $S$. oryzae caused $60 \%$ mortality in the two bioassays. In the third bioassay, isolate 573 caused $56 \%$, mortality, different from all others. In the fourth bioassay two isolates were noteworthy, 622 causing $78 \%$ mortality, and isolate 629 causing $51 \%$ mortality. All other isolates presenting the gene for protein Cry35Ba, had toxic activity against $S$. oryzae larvae below $50 \%$.

The low frequency with which effective isolates against the order Coleoptera is found has been reported by other authors, using different Cry protein classes, active against the order Coleoptera. Pinto and Fiúza (2003) collected soil samples from Rio Grande do Sul state, Brazil, and determined the genetic profile of 46 isolates, finding five with gene profile for the order Coleoptera. Similarly, Praça et al. (2004) detected only two isolates $(0.7 \%)$ effective against coleoptera among 300 isolates analyzed. In contrast Bravo et al. (1998) identified several cry genes in a collection of 496 isolates from soil samples collected in different regions of Mexico, and found 16 isolates presenting active crystal proteins against insects of the order Coleoptera. In the same direction, Ben-Dov et al. (1997) analyzed 215 isolates from the Asian continent and demonstrated the lack of isolates containing the cry3. Similar situation was reported by Chak et al. (1994), from a collection composed of 225 isolates obtained from soil samples in Taiwan, where different gene profiles were found, all with the lack of gene cry3. Thus few are the gene products with toxic potential for Coleoptera and in some cases they are lacking.

Among the diversity of known Cry proteins, new proteins have been reported with entomocide activity against the order Coleoptera, such as the protein class Cry35 (Ellis et al., 2002; Herman et al., 2002; Schenef et al., 2004), espe- 

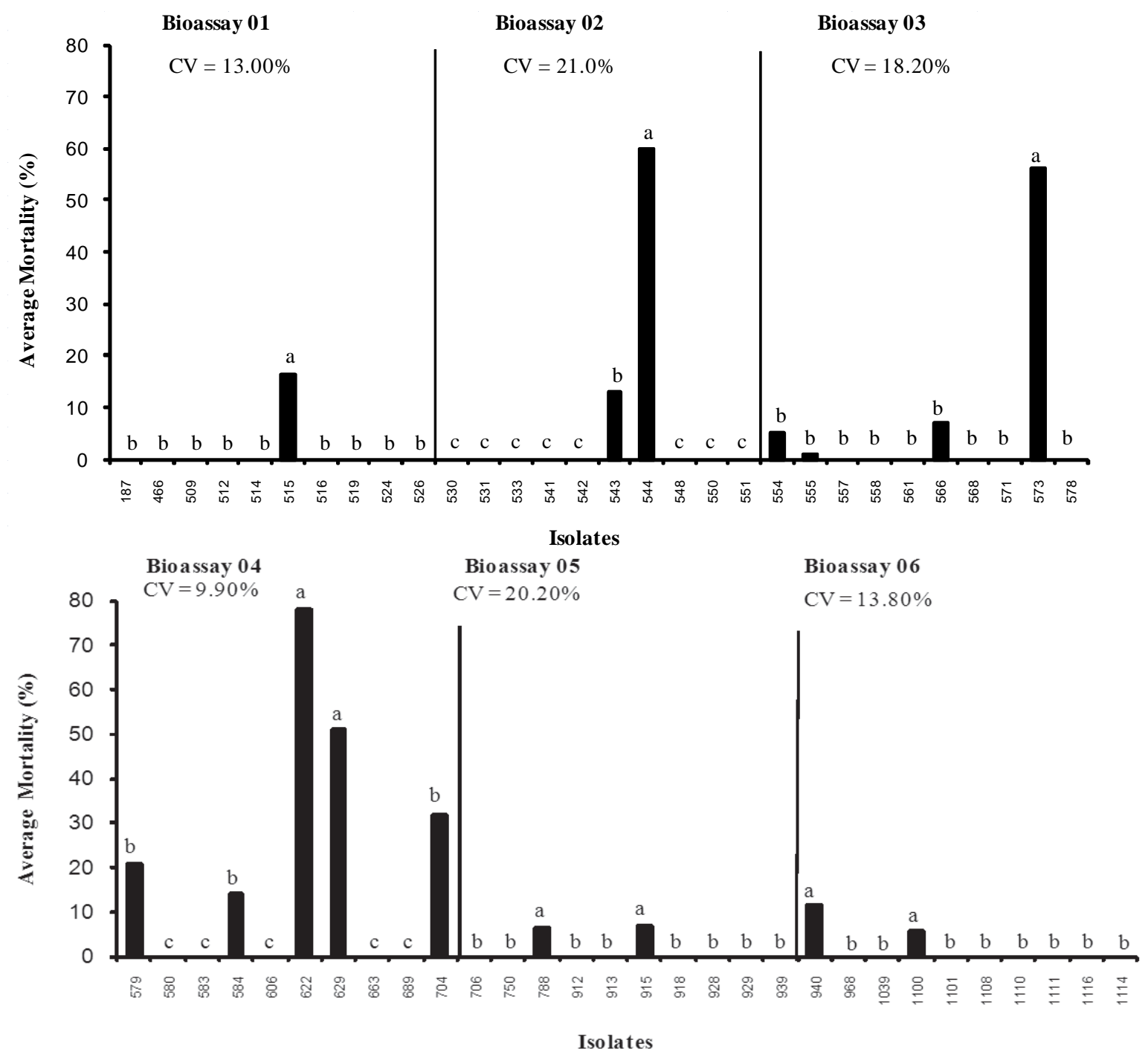

Figure 1 - Mortality caused by Bacillus thuringiensis isolates on Sitophilus oryzae larvae. Averages followed by the same letter do not differ (Tukey's test, $p<0.05$ ).

cially for insects of the family Chrysomelidade. Susceptibility of species in other families, such as Bostrichidae and Curculionidae has been studied for the other Cry proteins (Beegle, 1996; Saade et al., 1996), demonstrating that the bacterium $B$. thuringiensis can be an important source of different toxins, many of which with insecticide activity against species in the order Coleoptera.

Despite apparently simple, the study of the toxic activity of $B$. thuringiensis has some specific characteristics that must be considered. In this study, there were variations on the efficacy of the tested isolates against S. oryzae, of the order Coleoptera, that could be explained by a series of factors related to the mode of action of this pathogen, such as pro-toxin activation, toxin solubilization, binding of the activated protein to the larvae gut epithelium receptors, and insertion of the toxin in the membrane. This last factor is the one with the most complexity and, in general, is determinant for toxicity development in insect larvae gut (Bravo et al. 2007).
Although membrane insertion is the major determining factor for the susceptibility of a given species to the toxin Cry, Forcada et al (1996), observed that for $H$. virescens (Lepidoptera) digestive enzymes of resistant insect populations are capable of degrading the toxins in such a way that significantly the amount of active toxin in the gut in a given moment, reducing toxicity. Moreover, some toxins can bind to the receptors and this binding would not be sufficient to cause death of the insect larvae. The reason for the high binding affinity with little or no toxicity is still unknown, suggesting the initial binding of toxin-receptor could be a poor indicator of the receptor function in toxicity and that membrane insertion could be best correlated to toxicity (Aronson and Shay, 2001).

Isolates 544, 573, 622 and 629 of B. thuringiensis, presenting more than $50 \%$ efficacy against $S$. oryzae larvae, were selected for estimation of lethal concentration (Table 2). There were no differences between isolates 
544 and 622, indicating that they were the most virulent, since they presented the lowest $\mathrm{CL}_{50}$. However, between the two isolates, isolate 544 caused insect deaths with the lowest lethal concentration, followed by isolates 622 , 573 and 629. Better identification of these isolates was carried out by the morphological characterization, by scanning electron microscopy, of the crystals produced. This analysis highlighted three types of crystals for isolate 544: spherical, bi-pyramidal and cuboid, while isolates 573, 622 and 629 had spherical crystals (Figure 2).

The formation of crystals can be associated to the type of Cry protein and, consequently, to its cry gene (Höfte et al., 1989), providing indication about the insecticide activity of the crystals of an isolate (Taylor et al., 1992; Lereclus et al., 1993; Habib and Andrade, 1998). Thus, isolate 544 had in its morphological assembly a $130 \mathrm{kDa}$ bi-pyramidal protein (Figure 3) described as active against the order Lepidoptera (Schenepf et al., 1998).
These results were confirmed by PCR analysis, using the primer gral-cry1 described by Bravo et al. (1998) (data not shown). Cuboid crystals could be associated to protein type Cry2, also present in this isolate and confirmed by PCR (data not shown), presenting toxicity against Lepidoptera and Diptera (Höfte et al., 1988); however, this protein was not seen in SDS-PAGE, with a $70 \mathrm{kDa}$ size, according to Crickmore (2008).

The spherical formations, common to the studied isolates, suggest that this crystal morphology could be associated to toxicity of this bacterium to Coleoptera, since they also present a $44 \mathrm{kDa}$ protein profile (Figure 2) referring to protein Cry $35 \mathrm{Ba}$, active against Coleoptera (Ellis et al., 2002; Schnepf et al., 2005; Storer et al., 2006). These authors have described the binary action of $14 \mathrm{kDa}$ protein Cry34 with Cry35; however this study did not confirm their presence in the proteic and genetic profiles.
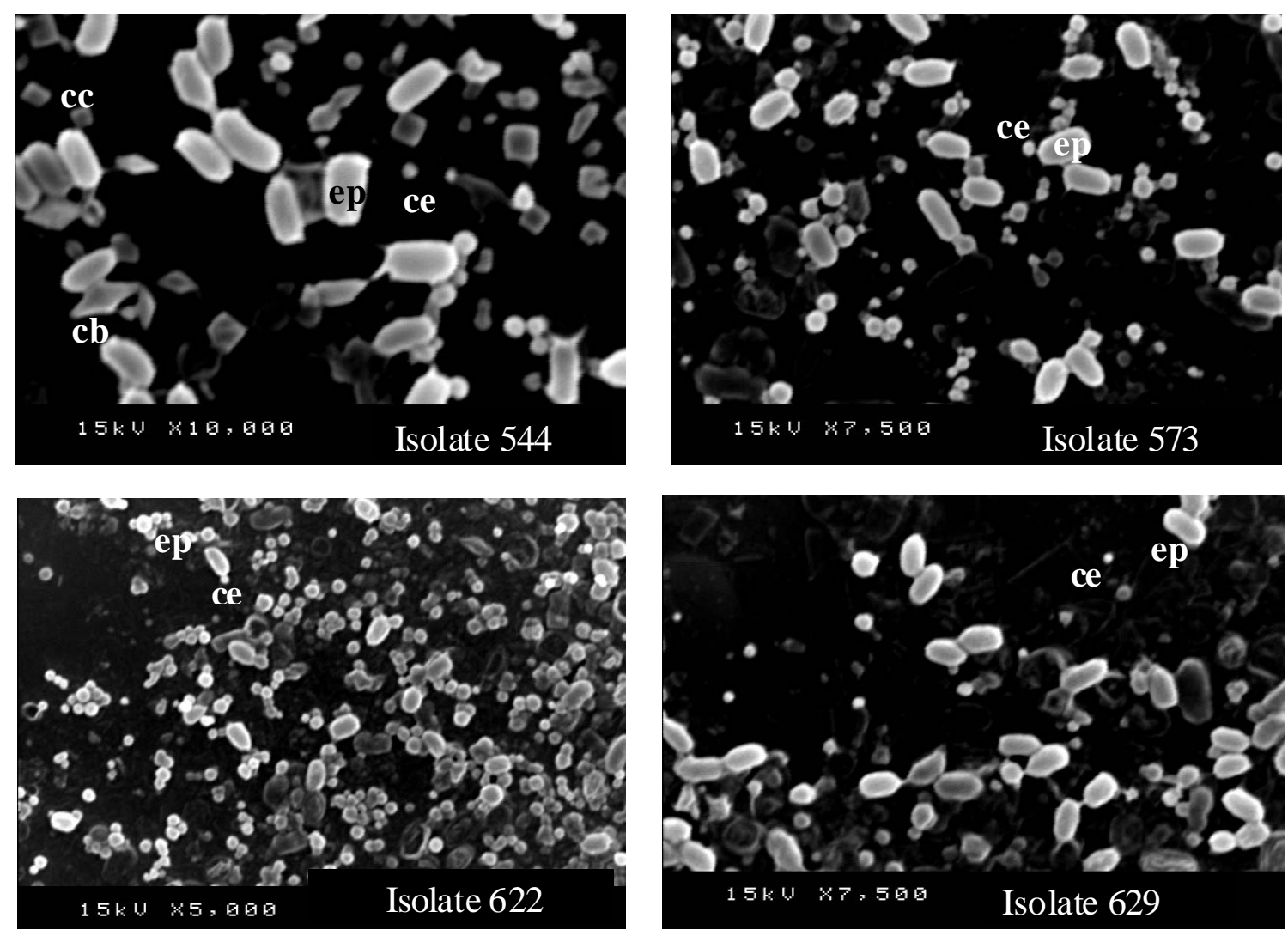

Figure 2 - Scanning electron micrography of the mixture spore-crystal; cb: bi-pyramidal crystal; cc: cuboid crystal; ce: spherical crystal; ep: spore.

Table 2 - Virulence test of Bacillus thuringiensis isolates against Sitophilus oryzae.

\begin{tabular}{lllll}
\hline Isolates & Regression equation & $\mathrm{LC}_{50}\left(\mathrm{IC}_{0.05}\right)$ & $\mathrm{n}^{\circ}$ & $\chi^{2}$ \\
\hline 544 & $\mathrm{y}=7.08+0.61 * \log$ & $4.70 \times 10^{3}\left(4.31 \times 10^{3}-6.1 \chi 10^{3}\right)$ & 120 & $6.79 \mathrm{n} . \mathrm{s}$ \\
573 & $\mathrm{y}=3.19+0.70 * \log$ & $3.55 \times 10^{5}\left(3.10 \times 10^{5}-4.11 \chi 10^{5}\right)$ & 120 & $8.60 \mathrm{n} . \mathrm{s}$ \\
622 & $\mathrm{y}=3.42+0.12 * \log$ & $9.14 \times 10^{3}\left(5.1 \times 10^{3}-6.40 \chi 10^{4}\right)$ & 120 & $6.49 \mathrm{n} . \mathrm{s}$ \\
629 & $\mathrm{y}=4.71+0.11 * \log$ & $7.03 \times 10^{5}\left(4.05 \times 10^{5}-5.90 \chi 10^{6}\right)$ & 120 & $7.01 \mathrm{n} . \mathrm{s}$ \\
\hline
\end{tabular}

n.s.: non significant, *significant at $5 \%, \mathrm{n}^{\circ}$ : number of tested insects/dose, tabulated $\chi^{2}=10.30$ 


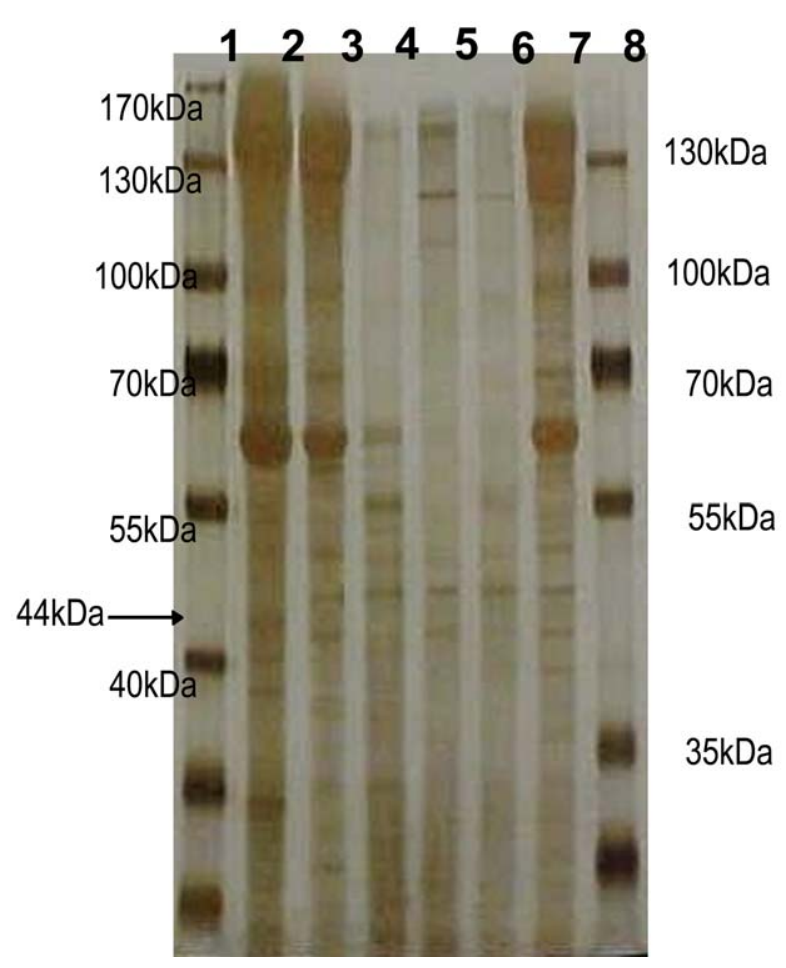

Figure 3 - Analysis of the mixture spore-crystal of $B$. thuringiensis by SDS-PAGE in $8 \%$ polyacrylamide gel.1: Molecular marker Fermentas Page Ruler ${ }^{\mathrm{TM}}$ Prestained protein Ladder Plus \#SM0671 2: var. toworthi, 3: isolate 544,4 : isolate 573 , 5: isolate 622, 6: isolate 629, 7: var. kurstaki HD-1, 8: Molecular marker Fermentas Page Ruler ${ }^{\text {TM }}$ Prestained protein Ladder Plus \# SM1811.

Other proteins were identified by SDS-PAGE analysis, demonstrating a $55 \mathrm{kDa}$ protein profile for isolates 573 and 629, indicating a new profile for them. A 120 $\mathrm{kDa}$ protein band was found for isolate 622 (Figure 2), which can indicate a new Cry protein, since this isolate did not present in its morphological profile the $120 \mathrm{kDa}$ bi-pyramidal crystal, described by Bravo et al. (1998). Moreover, this study highlights that the relations between the genetic profile for gene cry35Ba, the $44 \mathrm{kDa}$ proteins and the spherical morphology are present in all isolates effective against $S$. oryzae. No active isolate against $S$. oryzae larvae was found containing simultaneously the genes for the proteins Cry34 and Cry35Ba, and the lack of gene cry34, as proposed by the binary mode of action of Ellis et al. (2002) and Schnepf et al. (2005).

Several B. thuringiensis subspecies produce a series of other toxins besides the Cry proteins (Caballero and Ferré, 2001). Aranda et al. (1997) have used purified Cry proteins to detect their toxic activity each at a time. However this was not the aim of the present work that was carried out using spore/crystal suspension in the bioassays, with the possibility of one or more Cry proteins being expressed at one time as described by Fatoretto et al. (2007) and Álvarez et al. (2009).
Laboratory results are not always confirmed by field experiments, where there is some difficulty in evaluating some biological parameters (Polanczyk and Alves, 2005), thus reinforcing the need of control measures for S. oryzae in stored corn. An alternative would be the use of genetically modified corn, expressing the protein Cry35Ba of $B$. thuringiensis in the kernels, protecting them against $S$. oryzae larvae.

\section{Acknowledgements}

To Eliane Cristina da Cunha Alves for the technical assistance, to Prof. Dr. Jaime Maia dos Santos for the suggestions and advise on the morphological analyses, to Dr. João Carlos Campanharo for his dedication, teaching and patience that contributed for improvement of this study, and to all who assisted on its development. To CAPES and FAPESP for the financial support.

\section{References}

Abbot, W.S. 1925. A method of computing the effectiveness insecticide. Journal of Economic Entomology 18: 265-267.

Álvarez, A.; Virla, E.G.; Pera, L.M.; Baigorí, M.D. 2009. Characterization of native Bacillus thuringiensis strains and selection of an isolate active against Spodoptera frugiperda and Peridroma saucia. Biotechnol Lett. Available at: http:// www.springerlink.com/content/w7831n8595725h88. [Accessed Oct. 3, 2009]. DOI: 10.1007/s10529-009-0091-5.

Alves, S.B.; Moraes, S.B. 1998. Insect's pathogen inoculum quantification. p. 765-778. In: Alves, S. B. ed. Controle microbiano de insetos. FEALQ, Piracicaba, SP, Brazil. (in Portuguese).

Aranda, E.; Sanchez, J.; Peferoen, M.; Güereca, L.; Bravo, A. 1997. Interactions of Bacillus thuringiensis crystal proteins with the midgut epithelial cells of Spodoptera frugiperda (Lepdoptera: Noctuidae). Journal of Invertebrate Pathology 68: 203-212.

Aronson, A.I.; Shay, Y. 2001. Why Bacillus thuringiensis insecticidal toxin are so effective?: unique features of their mode of action. FEMS Microbiology Letters 195: 1-8.

Athié, I.; Paula, D.C. 2002. Biological aspects and identification: stored grains cereals insects. Varela, São Paulo, SP, Brazil. (in Portuguese).

Beegle, C.C. 1996. Efficacy of Bacillus thuringiensis against lesser grain borer Rhizopertha dominica (Coleoptera: Bostrichidae). Biocontrol Science and Technology 6:15-21.

Ben-Dov, E.; Zaritsky, A.; Dahan, E.; Barak, Z.; Sinai, R.; Manasherob, R.; Khamraev, A.; Troitskaya, E.; Dubitsky, A.; Berezina, N.; Margalith, Y. 1997. Extended screening by PCR for seven cry-group genes from field collected strains of Bacillus thuringiensis. Applied Environmental Microbiology 63: 4883-4890.

Bravo, A.; Sarabia, S.; Lopez, S.L.; Ontiveros, H.; Abarca, C.; Ortiz, A.; Ortiz, M.; Lina, L.; Villalobos, F.J.; Pena, G.; NunezValdez, M.E.; Soberon, M.; Quintero, R. 1998. Characterization of cry genes in a Mexican Bacillus thuringiensis strain collection. Applied Environmental Microbiology 64: 4965-4972.

Bravo, A.; Gill, S.S.; Soberón, M. 2005. Bacillus Thuringiensis: Mecanisms and use. p. 175-206. In: Gilbert, L.I.; Latrou, K.; Gill, S.S., eds. Comprehensive molecular inset science. Elsevier, New York, NY, USA.

Bravo, A.; Gill, S.S.; Soberón, M. 2007. Mode of action Bacillus thuringiensis: Cry and Cyt toxins and their potential for insect control. Toxicon 49: 423-435.

Caballero, P.; Ferré, J. 2001. Bioinsecticidas: fundamentos y aplicacionesde Bacillus thuringiensis en el control integrado de plagas. Phytoma, Valencia, Spain. 
Chak, K.F.; Chao, D.C.; Tseng, M.Y.; Kao, S.S.; Tuan, S.J.; Feng, T.Y. 1994. Determination and distribution of cry-type genes of Bacillus thuringiensis isolates from Taiwan. Applied Environmental Microbiology 60: 2415-2420.

Crickmore, N. Bacillus thuringiensis toxin gene nomenclature: full toxin list. Available at: http://www.lifesci.sussex.ac.uk/ home/Neil_Crickmore/Bt. [Accessed Jan. 14, 2008].

Davolos, C.C.; Guidelli-Thuler, A.M.; Abreu, I.L.; Sena, J.A.D.; Lemos, M.V.F. 2009. Cry1 genes from Bacillus thuringiensis: specificity determination and implications for primer design. Biotechnology Letters. Available at: http:// www.springerlink.com/content/g6n028jg26228778. [Accessed Oct. 3, 2009]. DOI:10.1007/s10529-009-0088-0.

Ellis, R.T.; Stockhoff, B.A.; Stamp, L.; Schnepf, H.E.; Schwab, G.E.; KNUTH, M.; Russell, J.; Cardineau, G.A.; Narva, K.E. 2002. Novel Bacillus thuringiensis binary insecticidal crystal protein active on western corn rootworm Diabrotica virgifera virgifera LeConte. Applied Environmental Microbiology 68: 1137-1145.

Fatoretto, J.C.; Sena, J.A.D.; Barreto, M.R.; Lemos, M.V.F.; Boiça Júnior, A.L. 2007. Association of bioassays and molecular characterization to select new Bacillus thuringiensis isolates effective against Spodoptera frugiperda (J.E. Smith) (Lepidoptera: Noctuidae). Neotropical Entomology 36: 737-745. (in Portuguese, with abstract in English).

Federici, B.A. 2005. Insecticidal bacteria: an overwhelming success for invertebrate pathology. Journal of Invertebrate Pathology 89: 30-38.

Forcada, C.; Alcácer, E.; Guarcera, M.D. 1996. Differences in the midgut proteolytic activity on two Heliothis virescens strain, on suceptible and one resistant to Bacillus thuringiensis toxins. Archives on Insect Biochemestry and Phisiology 32: 257-272.

Habib, M.E.M.; Andrade, C.F.S. 1998. Entomopathogenic bacteria. p. 383-446. In: Alves, S.B., ed. Controle microbiano de insetos. FEALQ, Piracicaba, SP, Brazil. (in Portuguese).

Herman, R.A.; Scherer, P.N.; Young, D.L.; Mihali ak, C.A.; Meade, T.; Woodsworth, A.T.; Stockhoff, B.A.; Narva, K.E. 2002. Binary insecticidal crystal protein from Bacillus thuringiensis, strain PS149B1: effects of individual protein components and mixtures in laboratory bioassays. Journal of Economic Entomology 95: 635-639.

Höfte, H.; van Rie, J.; Jansens, S.; van Hotven, A.; Vanderbruggen, H.; Vaeck, M. 1988. Monoclonal antibody análisis and insecticidal spectrum of three types of lepidopteran-specific insecticidal cristal protein of Bacillus thuringiensis. Applied Environmental Microbiology 54: 242-255.

Höfte, H.; Whiteley, H.R. 1989. Insecticidal crystal proteins of Bacillus thuringiensis. Microbiology Review 53: 242-255.

Juárez-Pérez, V.; Guerchicoff, A.; Rubinstein, C.; Delécluse, A. 2002. Characterization of $C y t 2 B c$ toxin from Bacillus thuringiensis subsp. medelin. Applied Environmental Microbiology 68: 12281231.

Laemmili, U.K. 1970. Cleavage of structural proteins during the assembly of the head of bacteriophage T4. Nature 227: 680-685.

Lereclus, D.; Delecluse, A.; Lecadet, M.M. 1993. Diversity of Bacillus thuringiensis toxins and genes. p. 37-70. In: Entwistle, P.F.; Cory, J.S.; Bailey, M.J.; Higgs, S., eds. Bacillus thuringiensis an environmental biopesticide: theory and practice. John Wiley, Chichester, England.
Moellenbeck, D.J.; Peters, M.L.; Bing, J.W.; Rouse, J.R.; Higgins, L.S.; Sims, L.; Nevshemal, T.; Marshall, L.; Ellis, R.T.; Bystrak, P.G.; Lang, B.A.; Stewart, J.L.; Kouba, K.; Sondag, V.; Gustafson, V.; Nour, K.; Xu, D.; Swenson, J.; Zhang, J.; Czapla, T.; Schwab, G.; Jayne, S.; Stockhoff, B.A.; Narva, K.; Schnepf, H.E.; Stelman, S.J.; Poutre, C.; Kziel, M.; Duck, N. 2001. Inseticidal proteins from Bacillus thuringiensis protect corn from corn rootworm. Nature Biotechnology 19: 668-672.

Nazarian, A.; Jahangiri, R.; Jouzani, G.S.; Seifinejad, A.; Soheilivand, S.; Bagheri, O; Keshavarzi, M.; Alamisaeid, K. 2009. Coleopteran-specific and putative novel cry genes in Iranian native Bacillus thuringiensis collection. Journal of Invertebrate Pathology 102: 101-109.

Pinto, L.M.N.; Fiúza, L.M. 2003. Distribution of cry genes on Bacillus thuringiensis isolates of ground from Rio Grande do Sul State, Brazil. Ciência Rural 33: 699-702. (in Portuguese, with abstract in English).

Polanczyk, R.A.; Alves, S.B. 2005. Biological parameters of Spodoptera frugiperda (J.E. Smith) (Lepidoptera: Noctuidae) assayed with Bacillus thuringiensis Berliner. Scientia Agricola 62: 464-468.

Praça, L.B.; Batista, A.C, Martins, E.S.; Siqueira, C.B.; Dias, D.G.S.D.; Gomes, A.C.M.M.; Falcão, R.; Monnerat, R.G. 2004. Bacillus thuringiensis lineages effective against insects to the orders Lepidoptera, Coleoptera and Diptera. Pesquisa Agropecuária Brasileira 39: 11-16. (in Portuguese, with abstract in English).

Saade, F.E.; Dunphy, G.B.; Bernier, R.L. 1996. Response of de carrot weevil Listronotus oregonensis (Coleoptera: Curculionidae), to strains of the Bacillus thuringiensis. Biological Control 7: 293298.

Sambrook, J.; Russel, D.W. 2001. Molecular cloning: a laboratory manual. Cold Spring Harbor, New York, NY, USA.

Schnepf, H.E.; Crickmore, N.; van Rie, J.; Lereclus, D.; Baum, J.; Feitelson, J.; Zeigler, D.R.; Dean, D.H. 1998. Bacillus thuringiensis and its pesticidal crystal proteins. Microbiology and Molecular Biology Reviews 62: 775-806.

Schnepf, H.E.; Lee, S.; Dojillo, J.; Burmeister, P.; Baum, J.; Fencil, K; Morera, L.; Nygaard, L.; Narva, K.E.; Wolt, J.D. 2005. Characterization of Cry34/Cry35 binary insecticidal proteins from diverse Bacillus thuringiensis strain collections. Applied Environmental Microbiology 71: 1765-1774.

Storer, N.P.; Babcock, J.M.; Edwards, J.M. 2006. Field measures of western corn rootworm (Coleoptera: Chrysomelidae) mortality caused by Cry34/35Ab1 proteins expressed in maize event 59122 and implications for trait durability. Journal of Economic Entomology 99: 1381-1387.

Taylor, R.; Tippet, J.; Gibb, G.; Pells, S.; Pike, D.; Jordan, L.; Ely, S. 1992. Identification and characterization of a novel Bacillus thuringiensis ä-endotoxin entomocidal to coleopteran and lepidopteran larvae. Molecular Microbiology 6: 1211-1217.

Thompson, J.D.; Higgins, D.G.; Gibson, T.J. 1994. Clustal W improving the sensitivity of progressive multiple sequence alignment through sequence weighting, position-specific gap penalties and weight matrix choice. Nucleic Acids Research 22: 4673-4680.

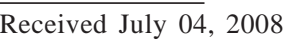

Accepted April 14, 2010 